\begin{tabular}{|l|l|l|}
\hline \multicolumn{2}{|c|}{ PublisherInfo } \\
\hline \hline PublisherName & $:$ & BioMed Central \\
\hline \hline PublisherLocation & $:$ & London \\
\hline \hline PublisherImprintName & $:$ & BioMed Central \\
\hline \hline
\end{tabular}

\title{
T cell microchimerism associated with HLA-DQA1*0501
}

\begin{tabular}{|l|l|l||}
\hline \multicolumn{2}{|c|}{ ArticleInfo } \\
\hline \hline ArticleID & $:$ & 153 \\
\hline \hline ArticleDOI & $:$ & $10.1186 /$ ar-2000-66843 \\
\hline \hline ArticleCitationID & $:$ & 66843 \\
\hline \hline ArticleSequenceNumber & $:$ & 110 \\
\hline \hline ArticleCategory & $:$ & Paper Report \\
\hline \hline ArticleFirstPage & $:$ & 1 \\
\hline \hline ArticleLastPage & $:$ & 3 \\
\hline \hline & & RegistrationDate : 2000-9-15 \\
\hline ArticleHistory & $:$ & OnlineDate \\
\hline \hline ArticleCopyright & $:$ & Current Science Ltd2000-9-15 \\
\hline \hline ArticleGrants & $:$ & \\
\hline \hline ArticleContext & $:$ & 130753311 \\
\hline \hline
\end{tabular}


Gerry Wilson,, Aff1

Affl University of Sheffield, UK

\section{Keywords}

Genetics, HLA, microchimerism, systemic sclerosis

\section{Context}

SSc is an autoimmune disease that is more common in women than men and shows strong association with MHC class II alleles (DR and DQ). The disease has been noted to have similarities with graftversus-host disease which is caused by chimerism. A possible explanation for the higher female incidence of SSc is that fetal cells may transfer to the maternal circulation during pregnancy and that their persistence in the circulation may precipitate disease. This group has previously demonstrated that fetal cells can be detected in both healthy women and SSc patients decades after childbirth and that the levels of these cells tends to be higher in patients compared with healthy controls (see Additional information). This study aimed to determine if maternal or fetal MHC class II genotypes are associated with persistent fetal microchimerism.

\section{Significant findings}

Microchimerism was detected in nine controls (47\%) and five SSc patients (42\%). Carriage of DQA $1 * 0501$ by either the mother or son was found to be associated with $\mathrm{T}$ cell microchimerism. The association appeared strongest with carriage of this allele by the son; indeed every women with microchimerism had a DQA1*0501-positive son whilst non-carriage of this allele by a son was associated with absence of microchimerism. Two mothers negative for microchimerism had DQA1*0501-positive sons suggesting that other factors are also involved. There was no association with the carriage of DRB $1 * 11$ or * 03 , alleles both of which are in strong linkage disequilibrium with DQA $1 * 0501$.

\section{Comments}


Microchimerism, resulting from the transfer of cells across the placenta, has been suggested as a contributing factor in the development of several autoimmune diseases. This study reports that carriage of DQA $1 * 0501$ by the offspring and possibly the mother, is associated with microchimerism for $\mathrm{T}$ cells in both healthy controls and systemic sclerosis (SSc) patients. Although small numbers were studied, it suggests that the DQA1*0501 association is independent of DRB1 alleles. This will need to be replicated in a larger cohort and also in different ethnic groups (that have different extended MHC haplotypes). The study raises the idea that the association of DQA $1 * 0501$ with scleroderma may be primarily related to the persistence of these fetal cells in the maternal circulation. The clinical similarity of scleroderma with chronic graft-versus-host disease suggests that the persistence of these foreign cells may activate the immune system leading to the increased risk of developing this autoimmune disease.

\section{Methods}

Two main groups were studied: 19 healthy controls and 12 with SSc, all of whom had given birth to at least one son, while three healthy nulligravid and three women with daughters only were used as controls. Nested PCR was used to amplify Y chromosome specific sequences using DNA extracted from peripheral blood $\mathrm{CD}^{+}$cells as a template. A sensitivity of 1 male cell in 50,000 female cells was achieved.

\section{Additional information}

Nelson JL, Furst DE, Maloney S, Gooley T, Evans PC, Smith A, Bean MA, Ober C, Bianchi DW: Microchimerism and HLA-compatible relationships of pregnancy in scleroderma. Lancet 1998, 351:559-562 (PubMed abstract).

\section{References}

1. Lambert NC, Evans PC, Hashizumi TL, Maloney S, Gooley T, Furst DE, Nelson JL: Cutting edge: persistent fetal microchimerism in T lymphocytes is associated with HLA-DQA1*0501: implications in autoimmunity. J Immunol. 2000, 164: 5545-5548.

This PDF file was created after publication. 